\title{
Deletion 18q Syndrome
}

National Cancer Institute

\section{Source}

National Cancer Institute. Deletion 189 Syndrome. NCI Thesaurus. Code C84522.

A condition in which some or all of the cells of the body contain extra genetic material from chromosome 18. Clinical features of this condition may include the following: spina bifida, hearing loss, cleft lip, cleft palate, undescended testes, rocker bottom feet, micrognathia, low set ears, cardiac anomalies (ventricular septal defect, atrial septal defect, patent ductus arteriosus, tetralogy of Fallot), intellectual disability, holoprosencephaly, pituitary dysplasia, seizures, autoimmune disorders, hip dysplasia, and/or congenital cataracts. 